\title{
CORREIOS DE DROGA: UM ESTUDO SOBRE A MEDIDA DA PENA NO SUPREMO TRIBUNAL DE JUSTIÇ $A^{1}$
}

\author{
DRUG COURIERS: A STUDY ON THE MEASURE OF PENALTY IN THE SUPREME \\ FEDERAL COURT
}

\section{CORREOS DE DROGA: UN ESTUDIO SOBRE LA MEDIDA DE PENA EN EL SUPREMO TRIBUNAL DE JUSTICIA}

\section{Manuel Simas-Santos ${ }^{2}$}

\section{Pedro Miguel Freitas ${ }^{3}$}

\section{João Simas-Santos ${ }^{4}$}

Licença CC BY:

Artigo distribuído sob os termos Creative Commons, permite uso e distribuição irrestrita em qualquer meio desde que o autor credite a fonte original.

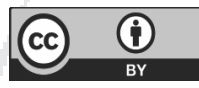

\begin{abstract}
Resumo: O programa de política criminal revê-se na punição infligida, por meio das molduras penais abstractas previstas nas diversas disposições que preveem
e punem a cada tipo legal de crime. Ultrapassando o modelo anterior, o Código das molduras penais abstractas previstas nas diversas disposições que preveem
e punem a cada tipo legal de crime. Ultrapassando o modelo anterior, o Código de 1982 veio vertê-las com grande amplitude e em grande número na parte especial. No quadro da divisão de tarefas entre o legislador e o julgador, que a individualização judicial das penas pressupõe no sistema português, aquele indicou genericamente os critérios a seguir por este nessa tarefa, do mesmo passo que assinalou expressamente, em alteração legislativa posterior, os fins das penas, indicações que não simplificam a prática judiciária e propiciam a ocorrência de disparidades injustificadas na aplicação das penas. Diversamente do que sucede na tradição e no sistema dos países anglo-saxónicos em que as guidelines em matéria de sentencing orientam os tribunais nesta matéria, em Portugal, os magistrados do Ministério Público e os juízes são deixados essencialmente entregues a si, importando conhecer a percepção que têm dessa problemática e contribuir para a coerência na aplicação das penas.
\end{abstract}

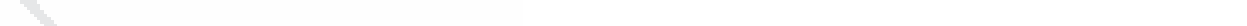

1 Este artigo corresponde, com algumas alterações, a parte da dissertação de mestrado intitulada "Moldura Penal Abstrata e Medida Concreta da Pena: Estudo empírico de prática judiciária, quanto aos correios de droga" que João Simas Santos apresentou em provas públicas no dia 18 de janeiro de 2018 no Instituto Universitário da Maia, sob a orientação de Pedro Miguel Freitas.

2 Professor Catedrático no Instituto Universitário de Maia, Portugal. Juiz conselheiro jubilado do Supremo Tribunal de Justiça de Portugal. Professor e coordenador da licenciatura em Criminologia no Instituto Universitário de Maia, Portugal. Membro da Sociedade Portuguesa de Psiquiatria e Psicologia da Justiça.

3 Doutor em Ciências Jurídicas Públicas (ciências jurídico-criminais) e Mestre em Direito Judiciário pela Escola de Direito da Universidade do Minho. Professor da universidade Católica do Porto- Portugal.

4 Mestre em Criminologia pelo Centro Univesitário de Maia. Procurador-adjunto, colocado na Procuradoria da Instância Local de Vila Nova de Gaia. Portugal. 
Palavras-Chave: Tráfico de drogas; Pena; Supremo Tribunal de Justiça

Abstract: The criminal policy program is reviewed in the punishment handed down, through the abstract criminal frameworks provided for in the various provisions that stipulate and punish each legal type of crime. Going beyond the previous model, the Code of 1982 gave them great scope and great number in the special part. In the context of the Division of tasks between the legislator and the judge, which the judicial individualization of penalties presupposes in the Portuguese system, it generally indicated the criteria to be followed by it in this task, while at the same time, it expressly signaled a subsequent legislative change, the end of the penalties, indications that did not simplify the legal practice, but led to unjustified disparities in the application of penalties. Contrary to the tradition and system of Anglo-Saxon, countries where sentencing guidelines guide the courts in this area, in Portugal, the magistrates of the Public Prosecution and the judges are essentially left to themselves. Therefore, it is important to know their perceptions of this problem, and contribute to consistency in the application of the penalties. In regard to drug trafficking, very severe penalties were generally imposed, which was extended to "drug couriers", in which the Supreme Court of Justice (STJ) began to draw up a table of essential data on its decisions, to increase the court's coherence in the application of penalties and contribute to guiding other legal courts. This led to the suggestion of the Project to deepen this experience and collect data on the condemnatory rulings of "drug couriers", the characterization of this category, the analysis and treatment of these data, comparison with the results of a previous study on the penalties applied to drug trafficking cases, seeking to obtain a an initial outline of occupation, by the judiciary, of the respective abstract framework, with the indication of the minimum and maximum limits of this occupation and the typical penalties applied.

Resumen: El programa de la política criminal se revé en la punición infligida, por medio de las molduras penales abstractas previstas en las diversas disposiciones que prevén y punen a cada tipo legal de crimen. Ultrapasando el modelo anterior, el Código de 1982 vino a verterlas con gran amplitud y en gran número en parte especial. En el cuadro de la división de tareas entre el legislador y el juzgador, que la individualización judicial de las penas presupone en el sistema portugués, aquel indicó genéricamente los criterios a seguir por este en esa tarea, del mismo modo que señaló expresamente, en alteración legislativa posterior, los fines de las penas, indicaciones que no simplifican la práctica judiciaria y propician la ocurrencia de disparidades injustificadas en la aplicación de las penas. Diversamente de lo que sucede en la tradición y en el sistema de los países anglosajones en que las guidelines en asunto de sentencing orientan a los tribunales en este asunto, en Portugal, los magistrados del Ministerio Público y los jueces son dejados esencialmente entregados a si, importando conocer la percepción que tiene de esta problemática y contribuir para la coherencia en la aplicación de las penas. En relación al tráfico de estupefacientes eran infligidas, en general, penas muy severas, lo que era extensible a los "correos de droga", caso en que el Supremo Tribunal de Justicia (STJ) inició la elaboración de una tabla con los datos esenciales de sus decisiones, para incrementar la coherencia del Tribunal en la aplicación de las penas y contribuir para la orientación de los otros tribunales judiciales, lo que sugirió el proyecto de aprofundar tal experiencia y recoger los datos referentes a las decisiones condenatorias de "correos de droga", a la caracterización de esta categoría, al análisis y al tratamiento de estos datos, a la comparación con los resultados del estudio anterior sobre las penas aplicadas en casos de tráfico de estupefacientes, buscando obtenerse un primer bosquejo de la mancha de ocupación, por la práctica judiciaria, de la respectiva moldura abstracta, con la indicación de los límites mínimos y máximos de esta ocupación y de penas típicas aplicadas. 


\section{INTRODUÇÃO}

O programa de política criminal, contido na Lei Penal, revê-se na punição infligida a cada tipo legal de crime, ou seja, nas molduras penais abstractas previstas nas diversas disposições que, na parte especial do Código Penal e legislação avulsa, preveem e punem os crimes aí elencados, via pela qual prossegue a Lei, designadamente fins de prevenção geral de intimidação e de integração. O Código Penal de $1982^{5}$ veio verter essas molduras na parte especial criando algumas dificuldades adicionais, a que se juntam as geradas pelos modelos de atenuação e agravação dessas mesmas molduras.

No quadro da divisão de tarefas que a individualização judicial das penas pressupõe no sistema português, o legislador indicou os critérios a seguir pelo julgador nessa tarefa, do mesmo passo que assinalou expressamente, em alteração legislativa posterior, os fins das penas. Indicações que proporcionam a elaboração de um discurso sobre a determinação da medida concreta da pena, mas não simplificam a prática judiciária correspondente e propiciam a ocorrência de disparidades injustificadas na aplicação das penas. Diversamente do que sucede na tradição e no sistema dos países anglo-saxónicos em que as guidelines em matéria de sentencing orientam os tribunais nesta matéria, entre nós, os magistrados do Ministério Público e os juízes são deixados essencialmente entregues a si mesmos.

Daí que seja interessante conhecer qual a evolução, que a esse propósito, se tem dado entre nós e qual a percepção que os magistrados têm dessa problemática. Anteriormente ao ano de $2000^{6}$, as decisões judiciais respeitantes ao tráfico de estupefacientes, regra geral, infligiam penas muito severas, em que, amiúde, se distinguia com dificuldade o grande tráfico do tráfico médio ou pequeno, mesmo, por vezes, na jurisprudência do Supremo Tribunal de Justiça (STJ), o que era extensível aos casos chamados de "correios de droga"7.

$5 \quad$ Ultrapassado o modelo do Código de 1886 (Código de 1852 revisto) de estabelecimento das molduras penais abstractas na parte geral do Código com ajustes na parte especial.

6 Ano em que as Secções Criminais do STJ sofreram uma grande renovação com a mudança total dos seus juízes.

7 Trata-se, como melhor se verá, de casos em que pessoas, frequentemente estranhas ao meio da droga, carenciadas economicamente, são aliciadas para, a troco de uma certa quantia, transportarem, muitas vezes no seu corpo, droga, para assim se ludibriarem as autoridades. 
Nesse caso, o próprio STJ sentiu a necessidade de iniciar a elaboração de uma tabela com os dados essenciais das suas decisões anteriores, na tentativa de incrementar a coerência do Tribunal na aplicação das penas em tais casos e, dessa forma, contribuir para a orientação dos outros tribunais judiciais. Surgiu, assim, como natural o projecto de aprofundar esta experiência do próprio STJ e recolher os dados respeitantes às decisões condenatórias de "correios de droga", à caracterização dessa categoria, à análise e ao tratamento desses dados à comparação com os resultados de estudo anterior sobre as penas aplicadas pelo STJ em casos de tráfico de estupefacientes.

Trata-se de uma investigação centrada sobre o uso da moldura penal abstracta pelo Supremo Tribunal de Justiça e as instâncias e poderá: (i) - Permitir ao conjunto dos tribunais uma reflexão fundamentada sobre a sua própria prática, em ordem a melhor respeitar o princípio de igualdade, a um melhor conhecimento e maior objectivação das motivações no domínio da medida da pena, e (ii) - Para aquele Tribunal um melhor cumprimento do seu papel de orientação dos restantes tribunais na aplicação da lei penal, (iii) - Para além de propiciar elementos eventualmente úteis ao legislador e ao ensino do direito.

Pretende-se um esboço de grelha da mancha de ocupação, pela prática judiciária, da respectiva moldura abstracta, com a indicação dos limites mínimos e máximos dessa ocupação e de penas típicas aplicadas.

\section{A TAREFA DE DETERMINAÇÃO DA MEDIDA DA PENA: ASPETOS ESSENCIAIS}

O programa de política criminal contido na Lei Penal revê-se na punição infligida a cada tipo legal de crime, ou seja, nas molduras penais abstractas previstas nas diversas disposições que preveem e punem, na parte especial do Código Penal e legislação avulsa, os crimes aí elencados. Prossegue a Lei, por essa via, designadamente fins de prevenção geral.

Esse objectivo é perturbado se, na prática judiciária, nem toda a amplitude das molduras penais previstas na Lei for efectivamente utilizada, ou o for num sentido contrário, ou ao menos divergente, do sinal contido na previsão legal. 
Nesta matéria intervém necessariamente o Parlamento, com a consequente discussão aberta a influências conjunturais de exigências do securitarismo ou do seu contrário, propícias à descaracterização qualquer projecto. O Código Penal actual, de 1982, aprovado pelo Decreto-Lei (DL) n. ${ }^{\circ}$ 400/82, de 23 de Setembro, sinaliza no seu preâmbulo as molduras penais e a sua função, tema a que voltou, no seu Preâmbulo, o DL n. ${ }^{\circ}$ 48/95, de 15 de Março, que reviu e republicou o Código Penal, de forma mais incisiva ${ }^{8}$, acentuando no seu ponto n. 8 a importância das modificações das molduras penais no sentido da tutela dos bens jurídicos pessoais em confronto com os patrimoniais.

Enquanto o Código anterior, Código Penal de 1886 (Código de 1852 revisto), estabelecia na parte geral - referimo-nos somente à prisão - 6 molduras penais abstractas, com ajustes na parte especial, sistema que propiciando um número limitado de molduras penais, com inegáveis vantagens, gerava penas severas e um sistema rígido que a prática judiciária combatia, acobertando-se nos mínimos legais e recorrendo excessivamente à atenuação extraordinária das penas (art. 94. $\left.{ }^{\circ}\right)$, o diploma de 1982 veio pulverizar o número de molduras penais abstractas para 50, que iam de 30 a 45 dias de prisão a 10 a 25 anos de prisão9. Mas este Código Penal foi objecto de múltiplas alterações que, como sugere o Preâmbulo do $\mathrm{DL}$ n. ${ }^{\circ}$ 48/95 de 15 de Março, modificaram as molduras penais, que baixaram, "mas de forma pouco sensível, passando a 43"10. Como já referimos noutro local, para além do grande número das molduras, podia-se constatar assimetrias e desequilíbrios entre elas, se consideradas no seu conjunto, sendo algumas delas seguramente dispensáveis e outras bastante mais amplas do que seria de esperar naquele conjunto. ${ }^{11}$ "Seria interessante fazer estudos quantitativos, quer

8 «Não sendo o único instrumento de combate à criminalidade, o Código Penal deve constituir o repositório dos valores fundamentais da comunidade. As molduras penais mais não são, afinal, do que a tradução dessa hierarquia de valores, onde reside a própria legitimação do direito penal».

9 Cfr. M. Leal-Henriques e M. Simas-Santos. O Código Penal de 1982. Lisboa: Rei dos Livros, 1986, Vol. I, pág. 257.

10 Cfr. M. Leal-Henriques e M. Simas-Santos. Código Penal. 2. a ed., Lisboa: Rei dos Livros, 1995, Vol. I, pág. 389393. No mesmo sentido. Código Penal. 3. ${ }^{a}$ ed., Lisboa: Rei dos Livros, 2002, Vol. I, 582-586.

11 E acrescentou-se «teria interesse analisar as molduras penais não só do ponto de vista da diferença entre o mínimo e o máximo, mas também do ponto da vista da relação entre o máximo e mínimo (na música e no ruído, v.g., aquilo que apercebemos iguais não são intervalos de diferença, mas intervalos de multiplicação). Por exemplo numa moldura penal de 30 dias a 5 anos de prisão, essa relação é de 60 , enquanto a diferença entre o máximo e o mínimo é de 4 anos e 11 meses, e numa moldura de 1 a 10 anos de prisão a relação é de 10 enquanto a diferença é de 9, consentindo a primeira moldura maior disparidade na aplicação concreta das penas do que esta última, não obstante a diferença ser nesta maior. M. Simas-Santos e M. Leal-Henriques. Código Penal, 2. ed., Lisboa: Rei dos Livros, 1995, Vol. I, pág. 392-393. 


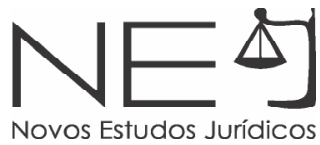

no âmbito da reforma penal, quer no âmbito da investigação, sobre a frequência de ocorrência das molduras, a frequência de ocorrência prática dos respectivos crimes e a distribuição das penas concretas dentro de cada moldura» ${ }^{12}$.

O número das molduras subiu entretanto significativamente no texto actual para 62, indo de 30 dias a 3 meses de prisão a 12 a 25 anos de prisão, e "esta atomização e multiplicação de molduras penais, agora agravada, não partiu de considerações éticas explícitas e claras quanto ao valor dos respectivos bens jurídicos numa inter-relação que apoie e esclareça os magistrados, dificultando que eles criem, neste domínio, um quadro referencial pessoal a partir da sua prática, e é muito vulnerável à modificação pontual dessas mesmas molduras, normalmente ao seu agravamento, numa legisferação à flor da pele e de deriva securitária» ${ }^{13}{ }^{14}$.

Vê-se, assim, uma grande dispersão das molduras penais, em contradição com o espírito dessa reforma de 1995 e alterações posteriores, criando algumas dificuldades adicionais. Com efeito, a dispersão das molduras dificulta a percepção da falada hierarquia de valores, e da inter-relação dos mesmos, que, uma vez interiorizada, poderia contribuir para uma individualização da pena mais justa e mais igualitária, com respeito pelo valor relativo daqueles valores fundamentais e a criação de referenciais gerais e para cada um dos juízes.

12 Sugeriram os mesmos AA., ob. e loc. cit.

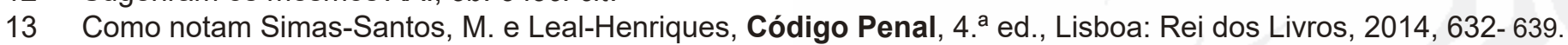

14 As 62 molduras penais previstas actualmente no Código Penal subirão ainda e muito significativamente se lhe somarmos as que resultariam da consideração da atenuação especial (art. ${ }^{\circ}$ s $72 .^{\circ}$ e $73 .^{\circ}$ do CP), bem ainda pela consideração do instituto da reincidência (art. $75 .^{\circ}$ do CP). 
A significativa amplitude de grande parte dessas molduras contribuiu também para aumentar a possibilidade de ocorrência de disparidades injustificadas nas penas pronunciadas pelos tribunais, como tivemos já oportunidade de referir ${ }^{15} 161718$.

Falamos até agora em molduras penais abstractas, mas é chegado o momento de nos referirmos às penas concretas, pela mão do legislador do DL n. ${ }^{\circ} 48 / 95$, de 15 de Março, que escreve significativamente no Preâmbulo: «[n]a verdade, mais do que a moldura penal abstractamente cominada na lei, é a concretização da sanção que traduz a medida da violação dos valores pressupostos na norma, funcionando, assim, como referência para a comunidade» (sublinhado nosso).

A concretização da sanção, de que fala o legislador do DL n. ${ }^{\circ} 48 / 95$, de 15 de Março, que funciona como referência para a comunidade é, pois, a pena concreta, a pena individualizada.

A tarefa de individualização da pena pressupõe no sistema português um quadro de divisão de tarefas entre o legislador e o julgador ${ }^{19}$. Ao legislador compete estabelecer, dentro de um mínimo e de um máximo, as molduras penais abstractas aplicáveis aos mesmos e a cada um dos tipos legais de ilícitos descritos na parte especial do Código Penal e na legislação avulsa. Mas cabe-lhe ainda definir «os critérios de que os aplicadores da lei devem lançar mão para determinar concretamente a pena dentro daqueles limites, ao juiz caberá,

15 Código Penal, 2. ${ }^{a}$ ed., Lisboa: Rei dos Livros, 1995, Vol. I, pág. 389-393. No mesmo sentido, Código Penal, 3 . $^{a}$ ed., Lisboa: Rei dos Livros, 2002, Vol. I, 582-586 e Código Penal, 4. ${ }^{a}$ ed., Lisboa: 4. ${ }^{a}$ ed., Lisboa: Rei dos Livros, 2014, 632- 639.

16 De notar que, como referem esses $\mathrm{AA}$, «O princípio da legalidade, a que já nos referimos, impede uma excessiva amplitude nessa moldura penal abstracta, sob pena de ser desrespeitado o comando nulla poena sine lege. E o princípio da proibição do excesso (art. $18 .^{\circ}$ da Constituição) impõe que essa moldura penal seja proporcional ao valor do bem jurídico protegido pela norma incriminadora e à gravidade da conduta tipificada.» - Noções de Direito Penal, 6. ${ }^{a}$ ed., 2018, Lisboa: Rei dos Livros, actualizada por Manuel SimasSantos e João Simas-Santos.

17 Refira-se que, contribuindo para a construção desses referenciais gerais, M. Simas-Santos e M. Leal-Henriques iniciaram os diversos capítulos da parte especial do CP com uma Nota Prévia com a menção dos tipos de crime, as molduras de cada um (simples, agravadas e atenuadas e respectivas razões), bem como as molduras penais previstas no capítulo, com a indicação dos crimes nelas incluídas, cfr Código Penal, $4 .^{a}$ ed., Lisboa: Rei dos Livros, volumes III e IV.

18 Determinação da medida da pena privativa da liberdade, um olhar crítico a partir do direito anglo-saxónico, 2016, Lisboa: Rei dos Livros, pág 19.

19 No direito penal português vigente, a tarefa de determinação da medida concreta da pena é resultado, pelo menos de forma mediata, da cooperação entre o legislador e o juiz - Castanheira Neves, "O princípio da legalidade criminal: o seu problema jurídico e o seu critério dogmático," em Estudos em homenagem ao Prof. Doutor Eduardo Correia, I, por AA.VV. (Coimbra: s/e, 1984), 346. 


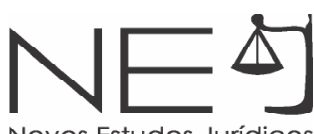

respeitando as balizas fixadas pelo legislador, dizer, em concreto, qual a pena que, no caso em apreço, deve ser aplicada ao agente» ${ }^{20}$.

Antes de atender a tais critérios e reportando-se ainda às molduras penais, o juiz terá de resolver um outro problema que se apresenta como prévio: encontrar a moldura legal abstracta que se aplica à situação concreta que lhe cabe julgar, através da definição do tipo de crime em julgamento. Resolvido aquele primeiro problema, um outro se coloca ao juiz: determinar a medida judicial da pena, o mesmo é dizer, estabelecer a pena concreta ajustada à conduta do agente, dentro da moldura legal ou abstracta que encontrou antes.

A aplicação da sanção penal obedece a diversos princípios, designadamente aosprincípios dalegalidade ${ }^{2122}$, da não retroactividade da lei penal desfavorável ${ }^{23}$, da retroactividade da lei penal mais favorável ${ }^{24}$, nulla poena sine culpa ${ }^{25}$, da proporcionalidade ${ }^{26}$, ne bis in idem $^{27}$, da jurisdição ${ }^{28}$, da motivação ${ }^{29}$, do direito

20 M. Simas Santos e M. Leal-Henriques. Noções de Direito Penal. 6. ${ }^{a}$ ed. 2018 Lisboa: Rei dos Livros, actualizada por M. Simas-Santos e J. Simas-Santos.

21 Que impõe, por um lado, que se atribua exclusivamente à lei a definição do que é crime, a enunciação das respectivas sanções e o estabelecimento dos pressupostos e das modalidades das medidas de segurança e, por outro, que todas essas definições têm de preexistir às situações às quais se aplicam. Resulta ainda deste princípio a exigência de lei expressa: não há crime nem pena sem lei certa - nullum crimen nulla poena sine lege certa; e sem lei escrita - nullum crimen nulla poena sine lege scripta.

22 A propósito fala Maria João Antunes. Consequências jurídicas do crime. Coimbra, 2007-2008, pág. 8, também no princípio da congruência ou da analogia substancial entre a ordem axiológica constitucional e a ordem legal dos bens jurídicos protegidos pelo direito penal (art. 18. ${ }^{\circ}$ da CRP).

23 Ninguém pode sofrer pena ou medida de segurança mais graves do que as previstas no momento da correspondente conduta ou da verificação dos respectivos pressupostos (n. 4 do art. $2 .^{\circ} \cdot{ }^{\circ},{ }^{\circ} 4$ do art. $29 .{ }^{\circ}$ da CRP, n. ${ }^{\circ} 2$ do art. $11 .^{\circ}$ da Declaração Universal dos Direitos do Homem, n. 1 do art. $49 .^{\circ}$ da Carta dos Direitos Fundamentais da União Europeia).

24 A plicam-se retroactivamente as leis penais de conteúdo mais favorável ao arguido $\left(n .^{\circ} 4\right.$ do art. $2 .^{\circ}$, n. $^{\circ} 4$, parte final, do art. $29 .^{\circ}$ da $\operatorname{CRP}$ e n. ${ }^{\circ} 1$, parte final, do art. $49 .^{\circ}$ da Carta dos Direitos Fundamentais da União Europeia).

25 A pena funda-se na culpa do agente pela sua acção ou omissão, pois é um juízo de censura ao agente por não ter agido de acordo com o dever jurídico, embora o tivesse podido conhecer e motivar-se por ele. Mas a medida culpa é também o limite da pena, de acordo com o disposto no n. 2 do art. $40 .^{\circ}$ do C. Penal.

26 Deriva do art. $18 .^{\circ}$ da Constituição, significando que a restrição dos direitos, liberdades e garantias só pode ter lugar nos casos expressamente previstos na Constituição e deve ser adequada, necessária e proporcional. $\mathrm{O}$ n. ${ }^{\circ} 3$ do art. $49 .{ }^{\circ}$ da Carta dos Direitos Fundamentais da União Europeia reafirma este mesmo princípio da proporcionalidade e indica um critério para a sua determinação ao prescrever «[a]s penas não devem ser desproporcionadas em relação à infracção».

27 De acordo com o princípio ne bis in idem ou nemo debet bis vexari pro una et eadem causa, consagrado no n. 5 do art. 29. ${ }^{\circ}$ da CRP, ninguém pode ser julgado mais do que uma vez pela prática do mesmo crime.

28 Compete em exclusivo aos tribunais, através dos juízes, a administração da justiça, mediante a garantia de um processo penal isento - nulla poena sine judicio,(arts. 32. ${ }^{\circ}$ e $202 .^{\circ}$ da CRP - função jurisdicional).

29 O dispositivo da sentença deve reflectir com clareza e precisão as operações de determinação da pena, mas é também necessário que na fundamentação o juiz exponha as operações que realizou pra chegar àquela sanção e que explique o porquê da medida da pena definitivamente aplicada ao arguido. A CRP (art. 205. ${ }^{\circ}$ consagra o dever geral de fundamentação das decisões judiciais, mas também é imposto no n. 3 do art. $71 .^{\circ}$ do C. Penal um dever especial de fundamentação: «na sentença são expressamente referidos os fundamentos da medida da pena.» 


\section{à revisão e indemnização ${ }^{30}, \mathrm{da}$ proibição da reformatio in pejus ${ }^{31}$ e o princípio} da igualdade. O princípio da legalidade, como vimos e é consabido, impede o juiz de criar o regime sancionatório respeitante a um crime. Só a lei é competente para definir os crimes e impor-Ihes sanções criminais. «[A] isto, Gomes Canotilho, Vital Moreira e Figueiredo Dias adicionam a proibição de molduras abstractas de penas demasiado amplas ${ }^{32}{ }^{33}$. Embora, como denota Figueiredo Dias, a exigência jurídico-constitucional de legalidade e determinação da pena se satisfaça com a previsão legislativa de mínimos e máximos legais da pena que corresponde a certo comportamento ${ }^{34}$, haverá sempre um limite decorrente do princípio da proporcionalidade da pena à amplitude da moldura abstracta ${ }^{35}{ }^{36}$.

30 Os cidadãos injustamente condenados têm direito, nas condições que a lei prescrever, à revisão da sentença e à indemnização pelos danos sofridos ( $n .^{\circ} 6$ do art. 29. da CRP), revisão essa que tem lugar através do recurso extraordinário previsto nos art. $^{\circ} \mathrm{S} 449 .^{\circ}$ a $466 .^{\circ}$ do CPP.

31 Se tiver sido interposto recurso de decisão final só pelo arguido, pelo Ministério Público, no exclusivo interesse da defesa, ou pelo arguido e pelo Ministério Público naquele exclusivo interesse, o tribunal superior não pode modificar, na sua espécie ou medida, as sanções constantes da decisão recorrida, em prejuízo de qualquer dos arguidos, ainda que não recorrentes (art. 409. ${ }^{\circ}$ do CPP). Princípio que tem igualmente aplicabilidade no recurso extraordinário para fixação de jurisprudência $-\mathrm{n} .^{\circ} 3$ do art. $443 .^{\circ}$ do $\mathrm{CPP}$.

32 G. Canotilho e V. Moreira. Constituição da República Portuguesa Anotada. I, 495 e 501-503, interpretam o princípio da tipicidade no sentido de dele extrair a exigência jurídico-constitucional de determinação legal do tipo de pena cabida a cada crime e, concomitantemente, a proibição de penas indefinidas ou de moldura "tão ampla que em tal redunde". Vide $\mathrm{n}^{\circ} .69$.

33 Figueiredo Dias. Direito Penal. II, 193, dá como exemplo uma pena de prisão com uma moldura abstracta entre 1 mês e 20 anos, para em seguida sustentar que não é tanto em razão do princípio da determinação que pugna pela inconstitucionalidade de uma tal moldura, mas sobretudo pelo princípio (jurídico-constitucional) da proporcionalidade da pena, aplicando o artigo $88 .^{\circ}$ da CRP por apelo a um argumento de identidade ou de maioria de razão. Ao tempo da sua escrita, 1993, o Manual convivia com a Constituição de 1992, cujo artigo $88 .^{\circ}$ se referia à actividade económica e investimentos estrangeiros, nos seguintes termos: "A lei disciplinará a actividade económica e os investimentos por parte de pessoas singulares ou colectivas estrangeiras, a fim de garantir a sua contribuição para o desenvolvimento do país e defender a independência nacional e os interesses dos trabalhadores". Este preceito, que agora se poderá encontrar no artigo $87 .{ }^{\circ}$, em nada tem que ver com a matéria em análise. Tratar-se-á de um lapso do Autor que porventura se queria referir a uma norma jurídico-constitucional (art. $\left.88 .{ }^{\circ}\right)$ que havia sido já revogada pela Lei n. ${ }^{\circ} 1 / 89$, de 8 de Julho $\left(2 .^{a}\right.$ revisão da CRP). A referida norma, epigrafada "Actividades delituosas contra a economia nacional", continha, no n. ${ }^{\circ} 1$, o seguinte texto: "As actividades delituosas contra a economia nacional são definidas por lei e objecto de sanções adequadas à sua gravidade". A doutrina de então servia-se deste preceito para justificar jurídico-constitucionalmente a existência de um princípio da proporcionalidade da pena. Acontece, porém, que em 1989 foi proposta, com sucesso, a sua eliminação do catálogo constitucional, deixando desamparado, pelo menos expressamente, o princípio da proporcionalidade da pena. De relevo neste aspecto é o entendimento de Costa Andrade, nesse momento deputado do PSD, sobre a proposta de eliminação, em virtude da sua inutilidade e desnecessidade, do então artigo $88 .^{\circ}$ da CRP: "Esta norma, apesar de tudo, tinha um sentido importante que penso ser já hoje património constitucional português: o princípio da proporcionalidade. O princípio da proporcionalidade, que é um princípio importante, não encontra na Constituição outro afloramento que não o deste preceito. É neste artigo que o preceito da proporcionalidade das penas, isto é, a adequação das penas à gravidade do ilícito e da culpa, encontra o único afloramento. E era para este artigo que a doutrina apelava quando se tratava de ancorar na Constituição fundamento para o princípio da proporcionalidade. Parece-me que este é hoje um dado tão evidente no nosso pensamento jurídico que já não se torna necessário tal afloramento expresso. Por estas razões, também não vemos qualquer razão para nos empenharmos na manutenção do preceito", cf. Diário da República, II Série, n. 30, 20-07-1988, p. 890.

34 Ibid.

35 A amplitude a partir da qual se põe em crise o princípio da tipicidade, para Gomes Canotilho e Vital Moreira, ou o princípio da proporcionalidade da pena é res que continua por determinar na doutrina.

36 Determinação da medida da pena privativa da liberdade, um olhar crítico a partir do direito anglo-saxónico. 2016, Lisboa: Rei dos Livros, pág 19. 
O último princípio, o da igualdade, reveste-se de especial importância no contexto desta investigação. Postula ele que todos os cidadãos têm a mesma dignidade social e são iguais perante a lei ( . $^{\circ} 1$ do art. $13 .^{\circ}$ da CRP), ninguém podendo ser privilegiado, beneficiado, prejudicado, privado de qualquer direito ou isento de qualquer dever em razão de ascendência, sexo, raça, língua, território de origem, religião, convicções políticas ou ideológicas, instrução, situação económica, condição social ou orientação sexual (n. $\left.{ }^{\circ} 2\right)$.

No domínio em que nos situamos, exige tal princípio que, quando sejam idênticos os pressupostos, deve ser dado o mesmo tratamento punitivo a todos os intervenientes, como é acentuado no direito adjectivo, para os não recorrentes (art. 402. ${ }^{\circ}$ do CPP) e, do mesmo modo, deve ser dado tratamento sancionatório diferenciado quando as condutas forem diversas.

Estabelecidas as bases teóricas relevantes para o objeto em estudo, passaremos então ao estudo empírico sobre a medida da pena no Supremo Tribunal de Justiça a propósito dos "correios de droga".

\section{ESTUDO EMPÍRICO}

\subsection{METODOLOGIA}

O fenómeno a estudar condiciona sempre, em qualquer estudo, a selecção da metodologia a aplicar. Portanto, o conhecimento que se obtém do fenómeno em estudo é influenciado pelo modo como o investigador o aborda, ou seja, a opção metodológica é ajustada consoante a problemática em estudo e a revisão da literatura ${ }^{37}$. Neste apartado apresentam-se a metodologia, o desenho e os métodos de investigação, recolha de dados, tratamento dos dados, objectivos, objecto e amostra do estudo. Apresentamse ainda os resultados encontrados bem como a sua discussão.

37 Clara Pereira Coutinho. Metodologia de Investigação em Ciências Sociais e Humanas: teoria e prática. $2^{\mathrm{a}}$ ed. reimp. Coimbra: Almedina, 2016. 


\subsubsection{DESENHO E MÉTODOS DE INVESTIGAÇÃO}

A presente investigação enquadra-se no paradigma positivista, ou seja, utiliza-se uma metodologia quantitativa, pois é inspirada numa ontologia realista em que se pretende uma confrontação empírica da problemática sob rigoroso controlo experimental, tendo a teoria sempre como orientação.

Portanto, é uma metodologia em que há uma verdade que pretende ser descoberta, não havendo explicações contraditórias, pois move-se num campo objectivo com a finalidade de encontrar generalizações capazes de controlar e prever os fenómenos em estudo. Sendo assim, é uma metodologia que se movimenta num campo dotado de determinismo, racionalidade, impessoalidade e previsão, valias num estudo científico ${ }^{38}$.

\subsubsection{Recolha dos dados}

Para este fim, utilizam-se métodos de recolha e análise. Quanto ao primeiro, dentro da família dos acórdãos judiciais, opta-se pelos acórdãos das secções criminais (3. ${ }^{a}$ e $5^{a}$ ) proferidos pelo STJ relativos ao tráfico de estupefacientes cometidos por "correios de droga". A recolha foi efetuada directamente em Bases de Dados:

- Oficial disponível em www.dgsi.pt e através do próprio sítio do STJ em http:// www.stj.pt/index.php/jurisprudencia-42213/basedados (57625 documentos, consulta efetuada em 9.12.2017, sendo que envolve matéria administrativa, cível e comercial, laboral e penal);

- Disponível na página oficial da Procuradoria-Geral Distrital de Lisboa ${ }^{39}$ elaborada com base na informação constante do Boletim Interno dos Sumários dos Acórdãos das Secções Criminais do Supremo Tribunal de Justiça, disponibilizado no seu sítio, com um total de 29.189 registos $^{40}$.

38 Clara Pereira Coutinho. Metodologia de Investigação em Ciências Sociais e Humanas: teoria e prática. $2^{\mathrm{a}}$ ed. reimp. Coimbra: Almedina, 2016.

39 http://www.pgdlisboa.pt/jurel/stj_main.php.

40 Consultado em 9.12.2017. 
- Pertencente ao Conselheiro Simas Santos, acessível na Internet, somente com registos penais do STJ e dos Tribunais das Relações com mais de 23000 registos ${ }^{41}$.

Foram também recolhidos elementos dos:

- Boletins Mensais dos Sumários das decisões das secções criminais do STJ disponíveis no sítio do STJ em http://www.stj.pt/index.php/jurisprudencia-42213/ sumarios, consultado em 9.12.2017; e da

- Colectânea de Jurisprudência relativa ao STJ42.

No que concerne ao método de análise, utiliza-se uma análise de conteúdo quantificada dos dados, ou seja, faz-se uma avaliação de forma sistemática dos acórdãos, com o objectivo de desvendar e quantificar a ocorrência dos dados levantados que possibilitem uma comparação posterior.

Foram recolhidos os seguintes elementos:

- Número do processo

- Tipo de droga

- Quantidade de droga

- Proveniência e percurso da droga

- Pena aplicada na instância

- Pena aplicada no STJ

- Sumário

- Data do acórdão

- Relator 
Novos Estudos Jurídicos

Os elementos foram recolhidos nas fontes indicadas tendo os resultados obtidos sido cruzados para detectar eventuais incorrecções ou omissões.

Foram recolhidos os acórdãos prolatados pelo STJ de Fevereiro de 2002 a Fevereiro de 2016 em matéria de tráfico de droga relativos a "correios de droga" em número de 282, sendo 214 casos com dados comparáveis e 68 em que não foi possível recolher dados referentes às penas aplicadas nas decisões recorridas.

A escolha deste crime em concreto teve em conta a realização de dois estudos no passado quanto às molduras do tráfico de estupefacientes simples e de menor gravidade que mostraram uma típica assimetria no preenchimento dessas molduras, com a quase totalidade das condenações a ficarem na primeira metade da moldura (90\% até 8 anos no primeiro estudo, $100 \%$ até 3 anos, no segundo) ${ }^{43}$.

Esses estudos, apesar dos seus limites, sugerem o interesse desta linha de investigação, tendo verificado curiosamente que há uma certa concentração das penas concretas em redor da média geométrica dos limites da moldura abstracta.

43 M. Simas-Santos e Manuel Matos. A medida da pena no Supremo Tribunal de Justiça no Tráfico de Estupefacientes (esboço de um estudo empírico). RPCC, 2004, pág. 453 e segs 
Na sequência dessas investigações, escolheu-se o tráfico simples de estupefacientes, previsto e punido pelo artigo 21. ${ }^{\circ}$ do $D L$ n. ${ }^{\circ} 15 / 93$, de 22 de Janeiro ${ }^{44}$, designadamente no seu n. ${ }^{0} 1$. Trata-se da legislação de combate à droga, publicada no uso da autorização legislativa concedida pela Lei n. ${ }^{0}$ 27/92, de 31 de Agosto ${ }^{45}$.

Dispõe-se nesse inciso, sob a epígrafe «Tráfico e outras actividades ilícitas», que: «1 - Quem, sem para tal se encontrar autorizado, cultivar, produzir, fabricar, extrair, preparar, oferecer, puser à venda, vender, distribuir, comprar, ceder ou por qualquer título receber, proporcionar a outrem, transportar, importar, exportar, fizer transitar ou ilicitamente detiver, fora dos casos previstos no artigo $400^{\circ}$, plantas, substâncias ou preparações compreendidas nas tabelas I a III é punido com pena de prisão de 4 a 12 anos. ${ }^{46}$ Trata-se de um crime que ocorre com frequência e que é punido com uma moldura penal abstracta relativamente ampla, em que o limite máximo é três vezes maior que o limite mínimo.

44 Retificação n. ${ }^{\circ}$ 20/93, de 20 de Fevereiro, alterado pelos DL n. ${ }^{\circ}$ 81/95, de 22 de Abril, Lei n. ${ }^{\circ}$ 45/96, de 3 de Setembro, DL n. ${ }^{\circ}$ 214/2000, de 2 de Setembro, Lei n. ${ }^{\circ}$ 30/2000, de 29 de Novembro, DL n. ${ }^{\circ}$ 69/2001, de 24 de Fevereiro, Lei n. ${ }^{\circ}$ 101/2001, de 25 de Agosto, Lei n. ${ }^{\circ}$ 104/2001, de 25 de Agosto, DL n. ${ }^{\circ}$ 323/2001, de 17 de Dezembro, Lei n. ${ }^{\circ}$ 3/2003, de 15, de Janeiro, Lei n. ${ }^{\circ} 47 / 2003$, de 22, de Agosto, Lei n. ${ }^{\circ}$ 11/2004, de 27 de Março, Lei n. ${ }^{\circ}$ 17/2004, de 17, de Maio, Lei n. ${ }^{\circ}$ 14/2005, de 26, de Janeiro, Lei n. ${ }^{\circ}$ 48/2007, de 29, de Agosto, Lei n. ${ }^{\circ}$ 59/2007, de 4 de Setembro, Lei n. ${ }^{\circ}$ 18/2009, de 11 de Maio, Lei n. ${ }^{\circ}$ 38/2009, de 20 de Julho, DL n. ${ }^{\circ} 114 / 2011$, de 30, de Novembro, Lei n. ${ }^{\circ}$ 13/2012, de 26 de Março, Lei n. ${ }^{\circ} 22 / 2014$, de 28 de Abril, Lei n. ${ }^{\circ}$ 77/2014, de 11, de Novembro, Lei n. ${ }^{\circ} 7 / 2017$, de 2, de Março.

45 Na sequência da aprovação da Convenção das Nações Unidas contra o Tráfico llícito de Estupefacientes e de Substâncias Psicotrópicas de 1988, assinada por Portugal e ratificada - Resolução da Assembleia da República n. ${ }^{\circ}$ 29/91 e Decreto do Presidente da República n. ${ }^{\circ}$ 45/91,DR IS, de 6 de Setembro de 1991- que visava prosseguir: (i) privar aqueles que se dedicam ao tráfico de estupefacientes do produto das suas criminosas, suprimindo, deste modo, o seu móbil ou incentivo principal e evitando, do mesmo passo, que a utilização de fortunas ilicitamente acumuladas permita a organizações criminosas transnacionais invadir, contaminar e corromper as estruturas do Estado, as comerciais e financeiras legítimas e a sociedade a todos os seus níveis; (ii) adoptar medidas adequadas ao controlo e fiscalização dos precursores, produtos químicos e solventes, substâncias utilizáveis no fabrico de estupefacientes e de psicotrópicos e que, pela facilidade de obtenção e disponibilidade no mercado corrente, têm conduzido ao aumento do fabrico clandestino de estupefacientes e de substâncias psicotrópicas; (iii) reforçar e complementar as medidas previstas na Convenção sobre Estupefacientes de 1961, modificada pelo Protocolo de 1972, e na Convenção sobre Substâncias Psicotrópicas de 1971, colmatando brechas e potenciando os meios jurídicos de cooperação internacional em matéria penal. Além do mais, reviu-se igualmente o DL n. ${ }^{\circ} 430 / 83$, de 13 de Dezembro.

46 É do seguinte teor o resto do artigo: «2 - Quem, agindo em contrário de autorização concedida nos termos do capítulo II, ilicitamente ceder, introduzir odiligenciar por que outrem introduza no comércio plantas, substâncias ou preparações referidas no número anterior é punido com pena de prisão de 5 a 15 anos.

3 - Na pena prevista no número anterior incorre aquele que cultivar plantas, produzir ou fabricar substâncias ou preparações diversas das que constam do título de autorização.

4 - Se se tratar de substâncias ou preparações compreendidas na tabela IV, a pena é a de prisão de um a cinco anos. 
Como lembrava o jornal Público, em 5 de Outubro de 2014, o número de correios de droga detidos em Portugal triplicou desde 2000, ano em que 63 pessoas foram detidas; 196 pessoas foram detidas pelas mesmas razões em 2013, de acordo com as estatísticas da Polícia Judiciária (PJ). Antes eram pessoas totalmente inseridas no meio da droga. Hoje pode ser quem passa por dificuldades ou ganhou a tentação do dinheiro fácil. Alguns são muito jovens... Ao longo desses anos, o primeiro salto deu-se entre 2000 e 2002, quando o total desses casos mais do que duplicou (passando de 63 para 132). O recorde foi atingido em 2006, com 232 detenções de correios de droga provenientes de voos internacionais, nos quais a PJ tem registada a apreensão de mais de 849 quilos de cocaína. O número de dados recolhidos, como se verá, confirma estes elementos.

Não se visam, no entanto, todas as condutas que cabem dentro desse tipo legal de crime, mas somente um mesmo tipo de condutas, idêntico no que se refere às características da acção empreendida e ao perfil do agente que se costuma designar na prática judiciária por "correios de droga", ou seja, pessoas vulneráveis social e ou economicamente, frequentemente sem antecedentes criminais e sem ligação a Portugal, que aceitam transportar drogas ilícitas, normalmente de um país para outro, a mando de traficantes com expressão, mediante contrapartida económica.

A análise recairá sobre as decisões do Supremo Tribunal de Justiça, por seis ordens de razões: (i) - é frequente o recurso para este Tribunal das condenações pela prática deste crime e nele se desenvolveu uma jurisprudência consistente de promoção da coerência na aplicação das penas, também em reacção às disparidades sentidas na prática judiciária das instâncias e que se traduziu pela elaboração interna de tabelas das penas aplicadas pelo STJ; (ii) - é um tribunal que se situa na cúpula da hierarquia judiciária, e foi concebido como regulador e uniformizador da jurisprudência nacional, cuja função própria e normal é restabelecer o império da lei, corrigindo os erros de interpretação e aplicação das normas jurídicas cometidos pelas Instâncias relação ou pelo tribunal da 1. ${ }^{a}$ instância, contribuindo para a uniformização da jurisprudência; (iii) - é um tribunal 


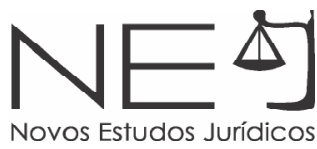

de âmbito nacional, o que permite isolar eventuais regionalismos e que, dado o número de juízes das Secções criminais (20), garante uma desejável diversidade; (iv) - o STJ produz anualmente um número significativo de decisões, cerca de 2.000; (v) estão disponíveis diversos registos das decisões do STJ, como já foi referido; (vi) - o próprio STJ, como se adiantou, elaborara já tabelas parcelares das penas anteriormente aplicadas em casos idênticos, que eram explicitamente consideradas nas decisões do Tribunal, como se vê do Acórdão prolatado no proc. n. ${ }^{\circ}$ 3240/07, em 11 de Outubro de 2007, relatado por um dos Autores ${ }^{47}$.

$\mathrm{Na}$ investigação tem-se em vista com o tratamento dos dados:

1. Traçar um quadro descritivo do que se deve considerar um correio de droga.

2. Relacionar a qualidade da substância (cocaína, heroína, haxixe) com a medida concreta da pena.

3. Relacionar a quantidade de substância apreendida com a medida concreta da pena.

4. Encontrar a pena média das penas concretas infligidas nos diversos processos.

5. Relacionar essa pena-média com as médias aritmética e geométrica dos limites máximos e mínimos da respectiva moldura penal abstracta.

6. Determinar qual é a "ocupação" que as penas concretamente infligidas fazem da amplitude da moldura penal abstracta, encontrando o intervalo entre a pena menos grave e mais grave.

7. Relacionar as penas aplicadas pelas instâncias e pelo STJ.

8. Relacionar a origem do tráfico e os percursos.

9. Analisar qualitativamente os acórdãos em que a pena se afasta claramente

47 Do acórdão relatado pelo Conselheiro Manuel Simas-Santos, consta uma tabela em uso no tribunal elaborada pelos juízes. 
Novos Estudos Jurídicos

da pena média para surpreender os factores de determinação concreta da pena a que o Supremo Tribunal de Justiça foi sensível, qual o discurso produzido.

\subsubsection{OBJECTIVOS DO ESTUDO}

Utilizou-se uma metodologia essencialmente quantitativa, procurandose com este projeto de investigação compreender a prática judiciária do Supremo Tribunal de Justiça, quer no uso que faz, em cada recurso que julga, da amplitude da moldura penal abstracta que ao crime cabe, quer na ponderação que igualmente faz ou não das suas decisões em casos anteriores idênticos e quais as consequências na sua prática, bem como no uso que também é feito pelas instâncias, em cada caso que julgam, da moldura penal abstracta aplicável ao crime de tráfico simples de droga, cometido por "correios de droga", o que poderá:

- permitir ao conjunto dos tribunais uma reflexão fundamentada sobre a sua própria prática, em ordem a melhor respeitar o princípio de igualdade, a um melhor conhecimento e maior objetivação das motivações no domínio da medida da pena, $\mathrm{e}$

- contribuir para reforçar a acção do Supremo Tribunal de Justiça no cumprimento do seu papel de orientação dos restantes tribunais na aplicação da lei penal, no domínio das sanções, para além de propiciar elementos eventualmente úteis ao legislador e ao ensino do direito.

\subsubsection{OBJECTO E AMOSTRA DO ESTUDO}

O presente estudo surge no âmbito da crescente preocupação com a coerência na determinação da medida concreta da pena. Tem-se como objecto de estudo as condenações em pena privativa da liberdade, proferidas pelo STJ, em recurso, no âmbito do tráfico simples de droga por "correios de droga" e a compreensão dos mecanismos internos de orientação na aplicação das penas que tome em consideração as penas anteriormente aplicadas pelo mesmo tribunal em casos idênticos anteriores. 


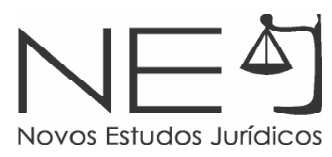

A amostra foi seleccionada segundo a técnica de amostragem não probabilística, pois foi apurada de acordo com determinados critérios tendo em conta os objectivos do trabalho, sendo, portanto, uma amostra intencional. Foram seleccionados todos os acórdãos que apresentassem os elementos requeridos (data, número de processo, relator, tráfico de drogas simples com intervenção de "correios de droga", tipo de substância, quantidade, pena, percurso) 275 acórdãos $(n=275)$. No mesmo acórdão pode existir mais do que uma condenação, por existiram mais de um arguido, "correio de droga", e por isso podem verificarse mais condenações do que acórdãos. O espaço temporal da amostra é desde Fevereiro de 2002 a Fevereiro de 2016.

\subsection{APRESENTAÇÃO E DISCUSSÃO DE RESULTADOS, CONCLUSÕES}

Apresentamos então os dados recolhidos, que foram transformados em informação através de uma análise estatística, e consequente discussão destes.

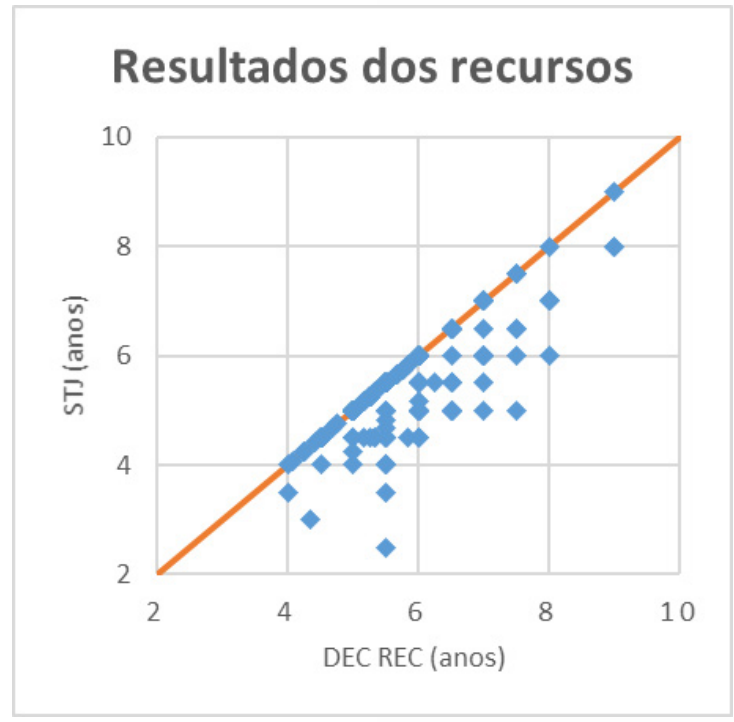

Figura 1 - Resultados dos recursos apreciados pelo STJ

Analisando as decisões do STJ em que se conseguiu recolher igualmente a pena aplicada na decisão recorrida, quando possível, verificamos que não houve nenhum caso de agravamento da pena aplicada nas instâncias, sendo certo que a grande maioria dos casos se tratava de recursos trazidos pela defesa e essa 
Novos Estudos Jurídicos

agravação seria impedida pela proibição de reformatio in pejus prescrita pelo art. 409. ${ }^{\circ}$ do CPP48. De qualquer forma, a análise qualitativa dos acórdãos não indicia que o STJ tivesse deixado de agravar penas que sentisse leves por causa dessa regra.

Antes se verificou desagravamento das penas aplicadas pelas instâncias.

Essa tendência já se tinha verificado no estudo já referido de Santos e Matos ${ }^{49}$ que na comparação entre as penas da 1. ${ }^{a}$ instância e o STJ notaram o desagravamento das penas que este último Tribunal efectuara e que sinalizaram abaixo da linha diagonal, na figura que então apresentaram e que aqui se reproduz:

\section{Comparação de penas}

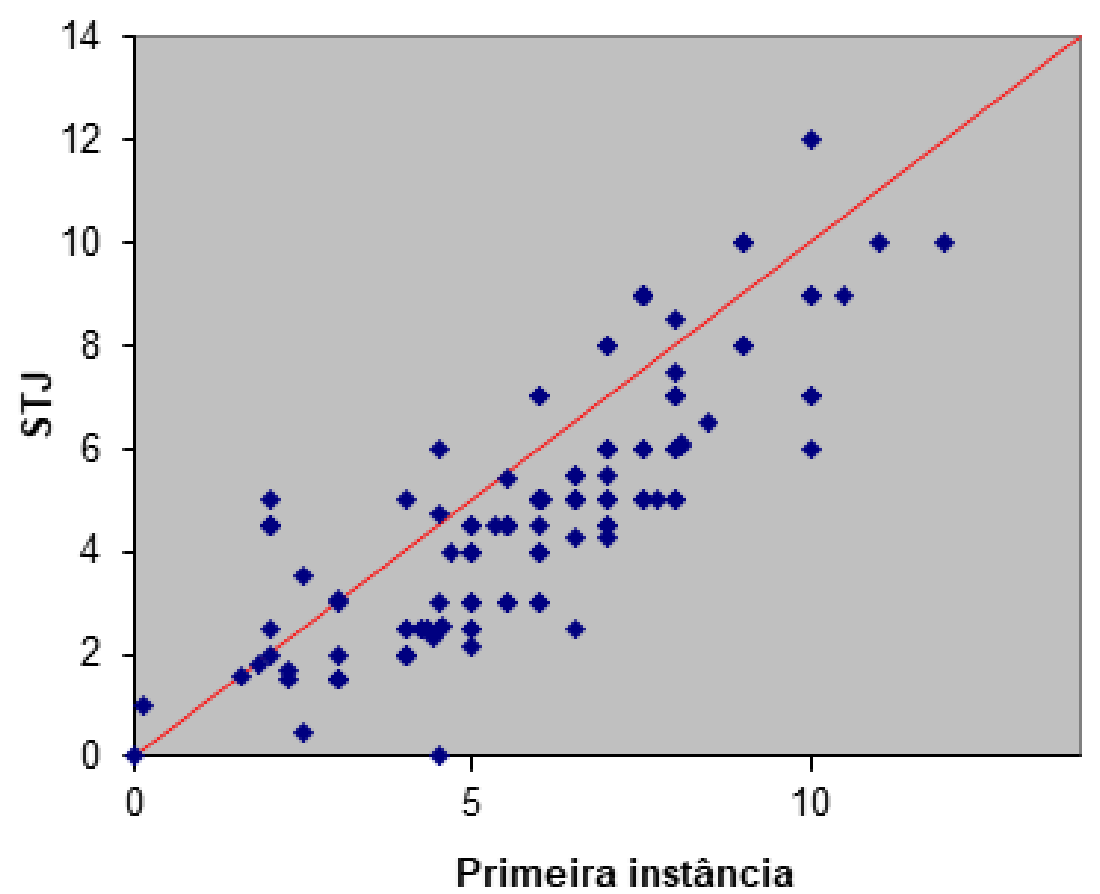

Figura 2 - Comparação das penas $1 .^{a}$ instância STJ (2004)

48 «(1) - Interposto recurso de decisão final somente pelo arguido, pelo Ministério Público, no exclusivo interesse daquele, ou pelo arguido e pelo Ministério Público no exclusivo interesse do primeiro, o tribunal superior não pode modificar, na sua espécie ou medida, as sanções constantes da decisão recorrida, em prejuízo de qualquer dos arguidos, ainda que não recorrentes. (2) - A proibição estabelecida no número anterior não se aplica à agravação da quantia fixada para cada dia de multa, se a situação económica e financeira do arguido tiver entretanto melhorado de forma sensível».

49 M. Simas-Santos e Manuel Matos. A medida da pena no Supremo Tribunal de Justiça no Tráfico de Estupefacientes (esboço de um estudo empírico). RPCC, 2004, pág. 453 e segs. 
Para esclarecimento da representação que usaram, socorreu-se à seguinte figura que mostra dois exemplos: desagravamento de 5 para 4 anos (ponto abaixo da diagonal) e agravamento de 10 para 12 (ponto acima da diagonal):

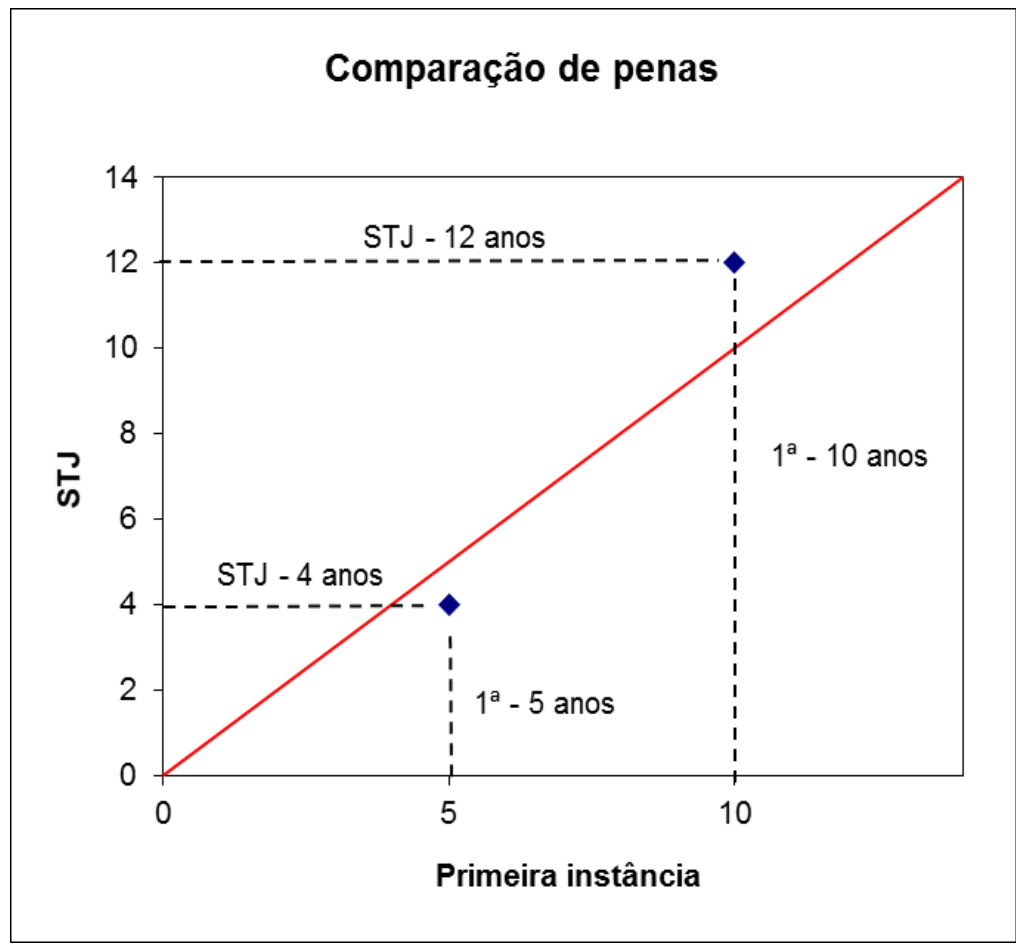

Figura 3 - Quadro explicativo da comparação das penas (2004)

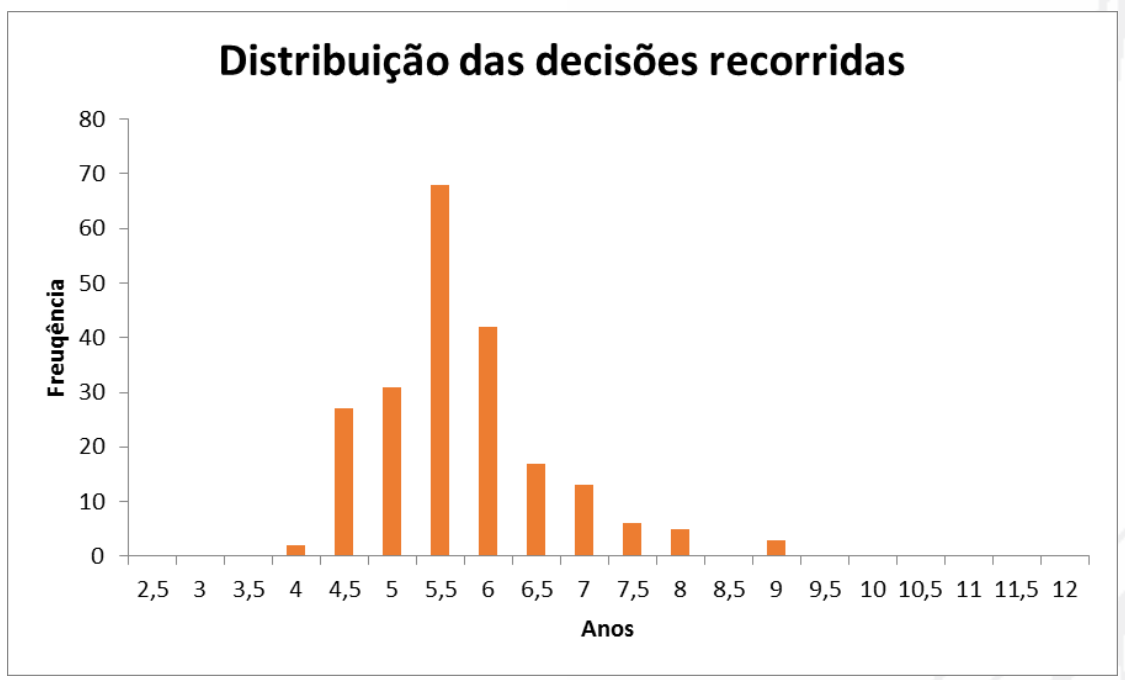

Figura 4 - Distribuição das penas pela moldura penal nas decisões recorridas 
Novos Estudos Jurídicos

A figura que antecede ${ }^{50}$ mostra a forma pela qual as penas aplicadas aos "correios de droga" nas decisões tomadas pelas instâncias recorridas, nos processos apreciados pelo STJ, ocuparam a moldura penal em causa de 4 a 12 anos, começando nos 4 anos, praticamente sem expressão, não ultrapassando os 9 anos de prisão, que tiveram lugar em 3 casos extremos ${ }^{51}$. A maior parte das penas concentraram-se nos 5 anos e 6 meses e 6 anos, com especial incidência nos 5 anos e 6 meses.

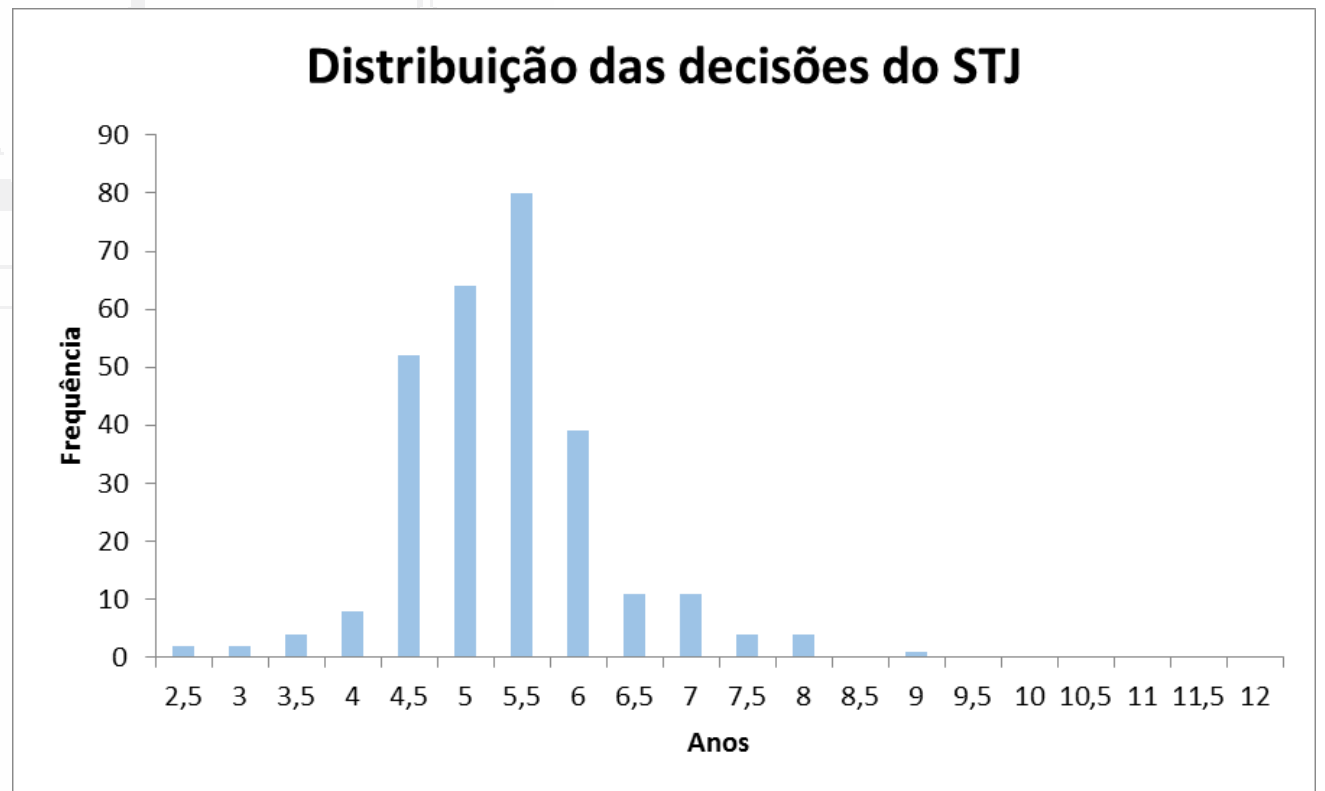

Figura 5 - Distribuição das penas pela moldura penal nas decisões do STJ

A figura que antecede mostra a forma pela qual as penas aplicadas aos "correios de droga" em todas as decisões tomadas pelo STJ e analisadas ocuparam a moldura penal em causa de 4 a 12 anos, não ultrapassando os 9 anos de prisão, que foram aplicados num único caso, que se não tratava afinal de um "correio de droga"52.

As penas aplicadas foram também especialmente atenuadas, embora com pouca expressão, tendo começado em 2 anos e 6 meses, 3 anos e 3 anos e 6 meses, mas a maior parte das penas aplicadas situaram-se entre 4 anos e 6 meses

50 O histograma da figura, e os que se seguem, agrupam casos semelhantes. Por exemplo a barra maior está nos 5,5 anos e corresponde a uma contagem de 68 casos situados entre 5 anos e 3 meses e 5 anos e 9 meses.

51 Um deles refere-se a um tráfico de $235 \mathrm{~kg}$ de cocaína, por via marítima, que não se considerou ser um correio, disponível em http://www.dgsi.pt/jstj.nsf/954f0ce6ad9dd8b980256b5f003fa814/fe4c437b0f53671c80257582005a 3699?OpenDocument, consultado a 4.01.2018.

Cfr nota anterior. 
e 5 anos e 6 meses, com especial incidência para os 5 anos e 6 meses, portanto valores inferiores aos das instâncias, traduzindo a já mencionada desagravação.

As penas inferiores ao limite mínimo da moldura penal abstracta considerada aplicadas pelo STJ foram-no em número de cinco: quatro em que o arguido viu a sua pena atenuada à luz do disposto no art. 9. ${ }^{\circ}$ do CP e art. $4 .^{\circ}$ do $\mathrm{DL} \mathrm{n} .^{\circ} 401 / 82$ de 23 de Setembro (jovem delinquente) ${ }^{53}$, e um em que a pena foi especialmente atenuada ao abrigo do disposto no art. $72 .^{\circ}$ do CP. ${ }^{54}$.

Foram aplicadas nove penas situadas no limite mínimo da respetiva moldura penal. ${ }^{55}$ Nota-se que a grande concentração das penas se deu entre os 4 anos e 6 meses e 5 anos e 6 meses.

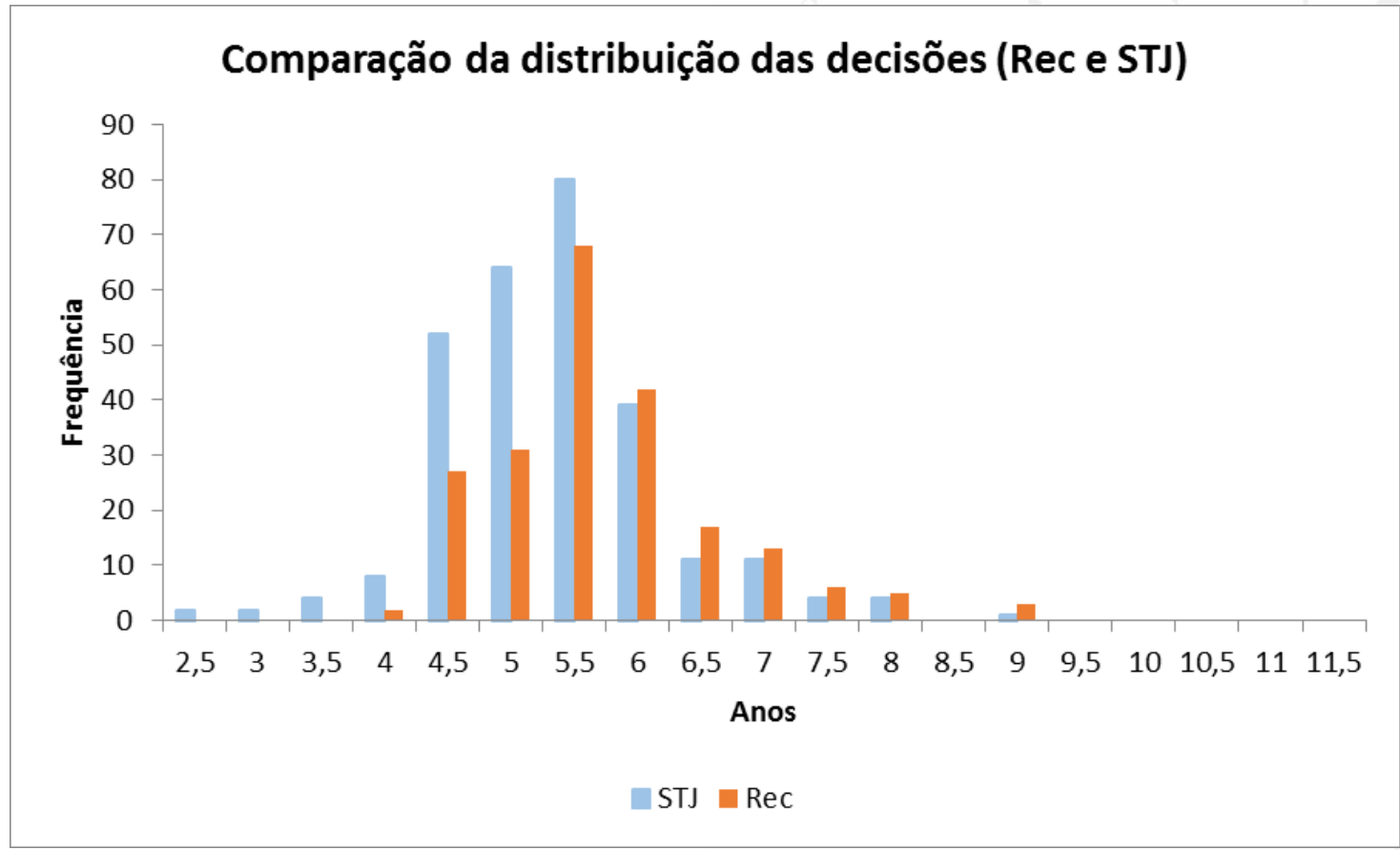

Figura 6 - Comparação da distribuição das penas nas decisões das instâncias e do STJ

53 Processos n. ${ }^{\circ}$ s 1641/04-3, 645/07-3, 2083707 e 3220/07.

54 Processo $n .^{\circ} 4308 / 06$. Estava em causa tráfico de haxixe em território nacional, do continente para os Açores, em que o STJ julgou relevante para o efeito a seguinte factualidade: - confessou os factos, integralmente e sem reservas; (i) - inicialmente sujeita à medida de coação de prisão preventiva, viu alterada a medida para a de permanência na habitação com vigilância electrónica, a qual tem cumprido sem incidentes, sendo que quando se realizou o julgamento, deslocou-se para Angra do Heroísmo sem acompanhamento policial ou carcerário durante a viagem, tendo estado detida durante o tempo em que permaneceu nos Açores por não haver ali condições para executar a vigilância electrónica; (ii) - foi autorizada a sair da residência para trabalhar; (iii)- vive em casa da mãe e com dois filhos de tenra idade (de 4 e 2 anos, à data do julgamento), tendo uma estreita ligação e bom relacionamento com as crianças, sendo harmonioso o ambiente familiar, conforme constatou o técnico que elaborou o relatório social, sendo que neste concluiu-se que "as características da personalidade da arguida e a ausência de antecedentes no contacto com a Justiça apontam, caso esta venha a ser condenada e a sua situação jurídica o possibilite, que esta possa ver a cumprir com sucesso uma medida alternativa".

55 Processos n. ${ }^{\circ}$ S 1641/04, 901/05 (2 casos), 6/07, 645/07, 3206/07, 1134/08-5, 1217/08-3 e 100/09.1JELSB.L1.S15. 
Nesta figura comparam-se as penas aplicadas pelas instâncias e pelo STJ, sendo visível a menor gravidade das penas aplicadas por este último Tribunal e uma diferente ocupação da moldura penal, bem como uma diferente concentração das penas aplicadas.

Uma comparação mais fina será, no entanto, feita mais adiante em figura em que só mostre dados comparáveis. Com efeito, no que se refere ao STJ e nas figuras que antecedem, foram tidos em conta todas as condenações pronunciadas pelo STJ, mesmo nos casos em que não foi possível recolher as penas aplicadas pelas instâncias nas decisões recorridas.

Daí que importe considerar também em conjunto somente as decisões do STJ que foram proferidas em recursos em que foi possível recolher as penas aplicadas pelas instâncias, nas decisões recorridas, portanto ter penas perfeitamente comparáveis, na distribuição que se efetua na moldura penal abstracta considerada de 4 a 12 anos de prisão.

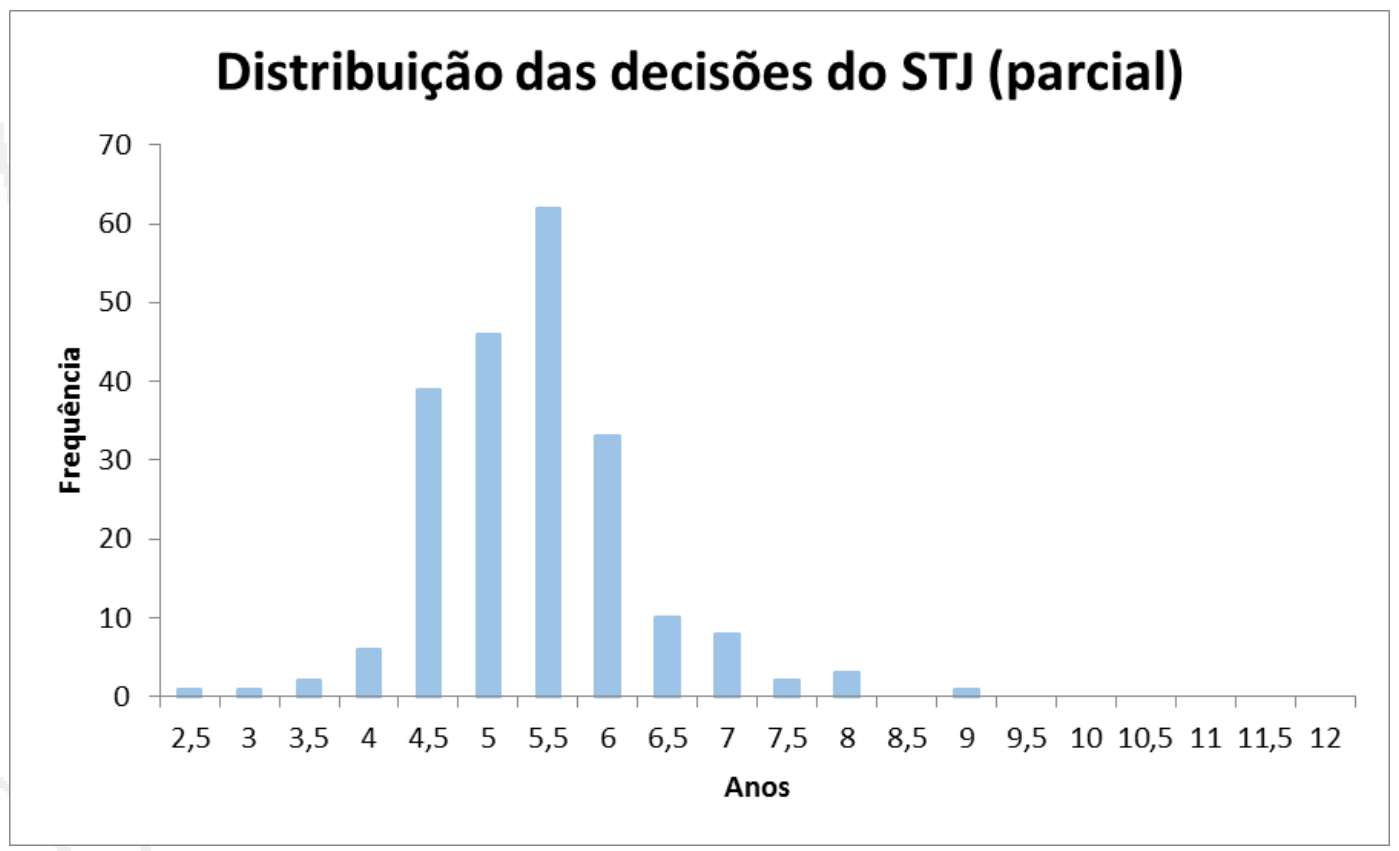

Figura 7 - Distribuição das penas pela moldura penal nas decisões do STJ (parcial)

A figura que antecede mostra a forma pela qual as penas aplicadas aos "correios de droga" nas decisões tomadas pelo STJ, em que foram recolhidos os dados referentes às penas aplicadas nas decisões recorridas, ocuparam a moldura penal em causa de 4 a 12 anos, não ultrapassando os 9 anos de prisão. 


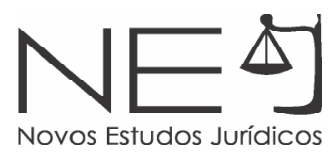

A maior parte das penas aplicadas situaram-se entre 4 anos e 6 meses e 5 anos e 6 meses, com especial incidência em 5 anos e 6 meses, portanto valores inferiores aos das instâncias.

Como se disse já, foi feito uso da faculdade de atenuação especial da pena, embora com pouco expressão ${ }^{56}$, mas a maior parte das penas aplicadas situaram-se entre 4 anos e 6 meses e 5 anos e 6 meses, com especial incidência para os 5 anos e 6 meses, portanto valores inferiores aos das instâncias, traduzindo a já mencionada desagravação.

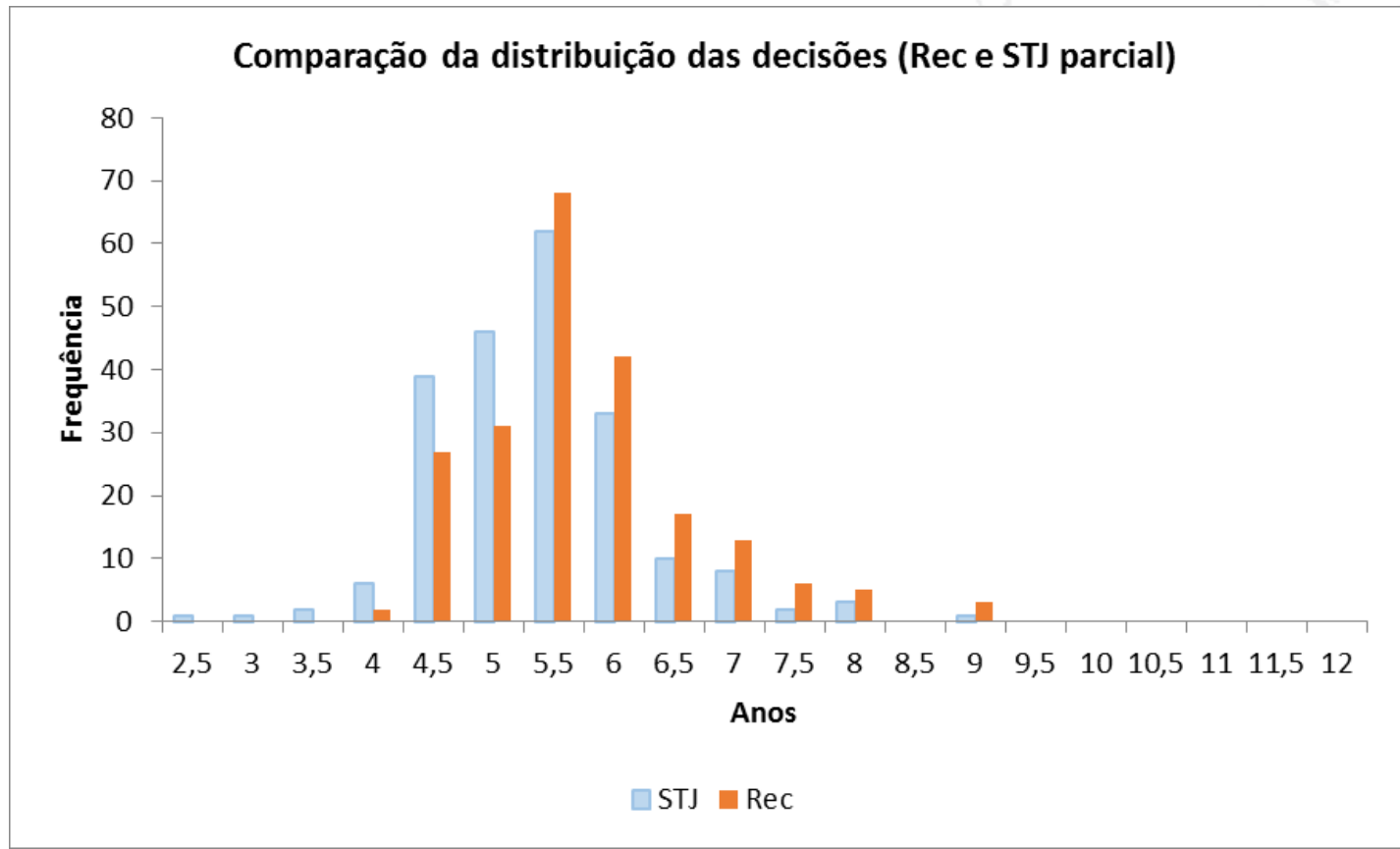

Figura 8 - Comparação da distribuição das penas nas decisões das instâncias e do STJ (parcial)

Da comparação da distribuição das penas aplicadas pelas instâncias e pelo STJ nos mesmos processos resulta que as penas aplicadas por este último Tribunal são em geral menos graves, sendo que o STJ não só atenuou especialmente as penas nos casos já assinalados, diversamente do que sucedeu com as instâncias como aplicou menos penas mais graves. Resulta ainda que as penas aplicadas pelas instâncias se situaram essencialmente entre os 4 anos e 6 meses e os 6 anos e 6 meses, com prevalência para os 5 anos e 6 meses e os 6 anos, enquanto que no STJ elas se concentraram entre os 4 anos e 6 meses e os 6 anos, com prevalência para os 4 anos e 6 meses a 5 anos e 6 meses.

56 Penas de 2 anos e 6 meses, 3 anos e 3 anos e 6 meses. 
Verifica-se ainda que o STJ, directamente através da consideração expressa das penas que vinha aplicando, concentrou essencialmente a aplicação das penas num "espaço" limitado da moldura penal (4 anos e 6 meses e os 6 anos e 6 meses: 2 anos em 8), promovendo a coerência na aplicação das penas quanto a este crime e estes agentes. E indirectamente, através da divulgação da sua jurisprudência reiterada e mantida, influenciou e orientou as instâncias no mesmo sentido, com resultados sensivelmente próximos dos alcançados no seu domínio directo.

São os seguintes os Dados Numéricos trabalhados:

\begin{tabular}{lrc}
\hline & \multicolumn{1}{c}{ Anos } & Meses \\
Média Decisões Recorridas & 5,674455 & \\
Média STJ parcial & 5,330607 & \\
Média STJ global & 5,287234 & \\
Desvio padrão Decisões Recorridas & 0,92971 & 11,15652 \\
Desvio padrão STJ parcial & 0,867762 & 10,41314 \\
Desvio padrão STJ global & 0,892626 & 10,71151 \\
& & \\
Valor mais frequente (moda) decisões recorridas & 5,5 & \\
Valor mais frequente (moda) STJ global & 5,5 & \\
& & \\
Mediana Decisões Recorridas & 5,5 & \\
Mediana STJ global & 5,25 & \\
\hline
\end{tabular}

Figura 9 - Dados numéricos trabalhados ${ }^{57}$

No que se refere aos Intervalos de Confiança (STJ global), optou-se por calcular os níveis de confiança para intervalos pré-estabelecidos, com o significado de que 90\% das penas aplicadas pelo STJ estão entre 3 anos e 9 meses e 6 anos e 9 meses; 80\% estão entre 4 anos e 6 meses e 6 anos e mais de metade estão entre 4 anos e 9 meses e 5 anos e 9 meses.

Intervalos centrados na mediana $(5,25-50300)$

Intervalo 1: \pm 6 meses $(40900-50900)$ - probabilidade $=52 \%$

Intervalo 2: \pm 9 meses $(40600-60000)$ - probabilidade $=80 \%$

57 Os valores do desvio padrão, medida de espalhamento dos dados em relação à média, correspondem à amostra. Apresenta-se também a mediana, o número de penas superiores é igual ao número de penas superiores. 


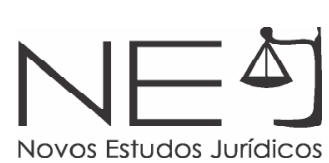

Intervalo 3: \pm 18 meses $(30900-60900)-$ probabilidade $=90 \%$

Trabalhados a partir da amostra, intervalos centrados na mediana. Foram centrados na mediana e não na média, dada a natureza discreta da distribuição empírica (uma vez que a média não é uma pena) (as curtas parecem, mas não são continuas - as penas não são ditadas em dias, ou até em horas).

Embora nas condutas em causa a variação das quantidades de droga sejam limitadas, entendeu-se interessante analisar as variações das penas em função das quantidades traficadas.

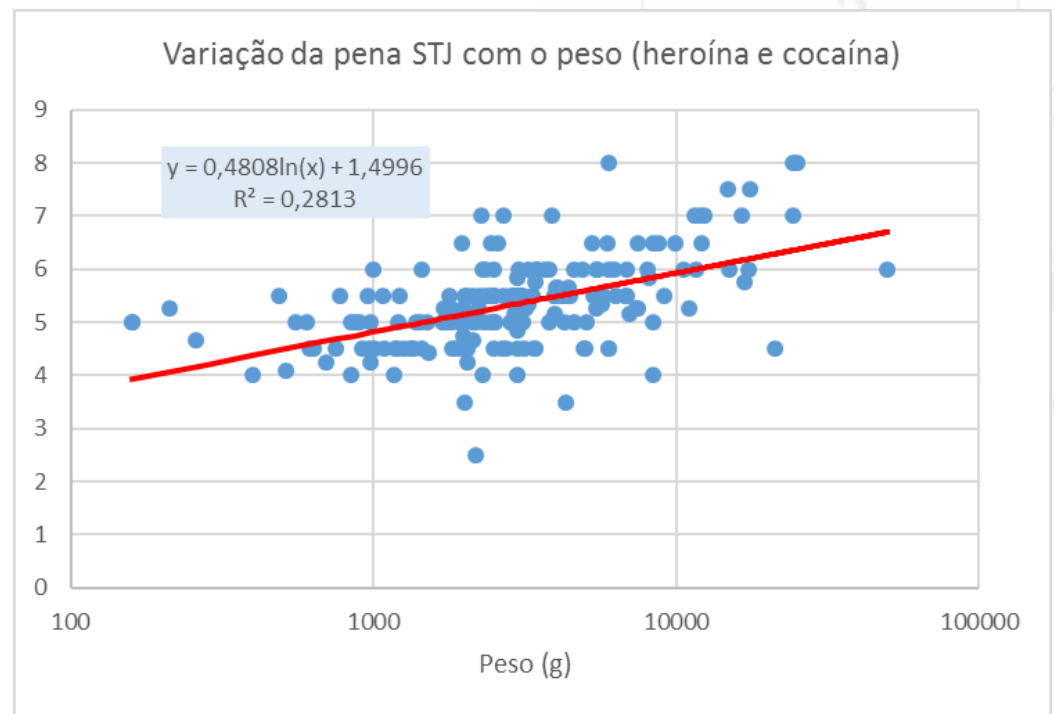

Figura 9 - Variação da pena no STJ com o peso (heroína e cocaína)

O peso tem alguma influência na pena, mas a correlação é baixa $(0,508)$. A correlação da pena com o logaritmo natural do peso é um pouco melhor $(0,554)$ As rectas de regressão foram obtidas pelo método dos mínimos quadrados ${ }^{58}$.

58 Procurou-se encontrar a recta assinalada, calculando a soma dos quadrados dos desvios de todos os pontos, e que minimiza o quadrado dos desvios de todos os pontos. 


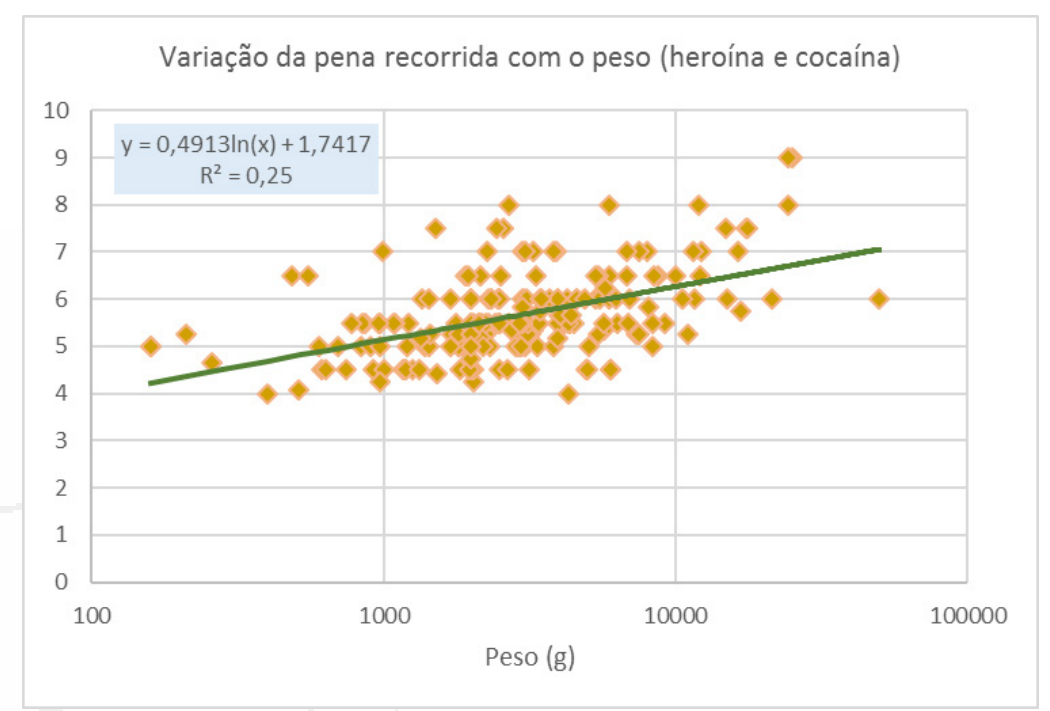

Figura 10 - Variação da pena nas decisões recorridas com o peso (heroína e cocaína)

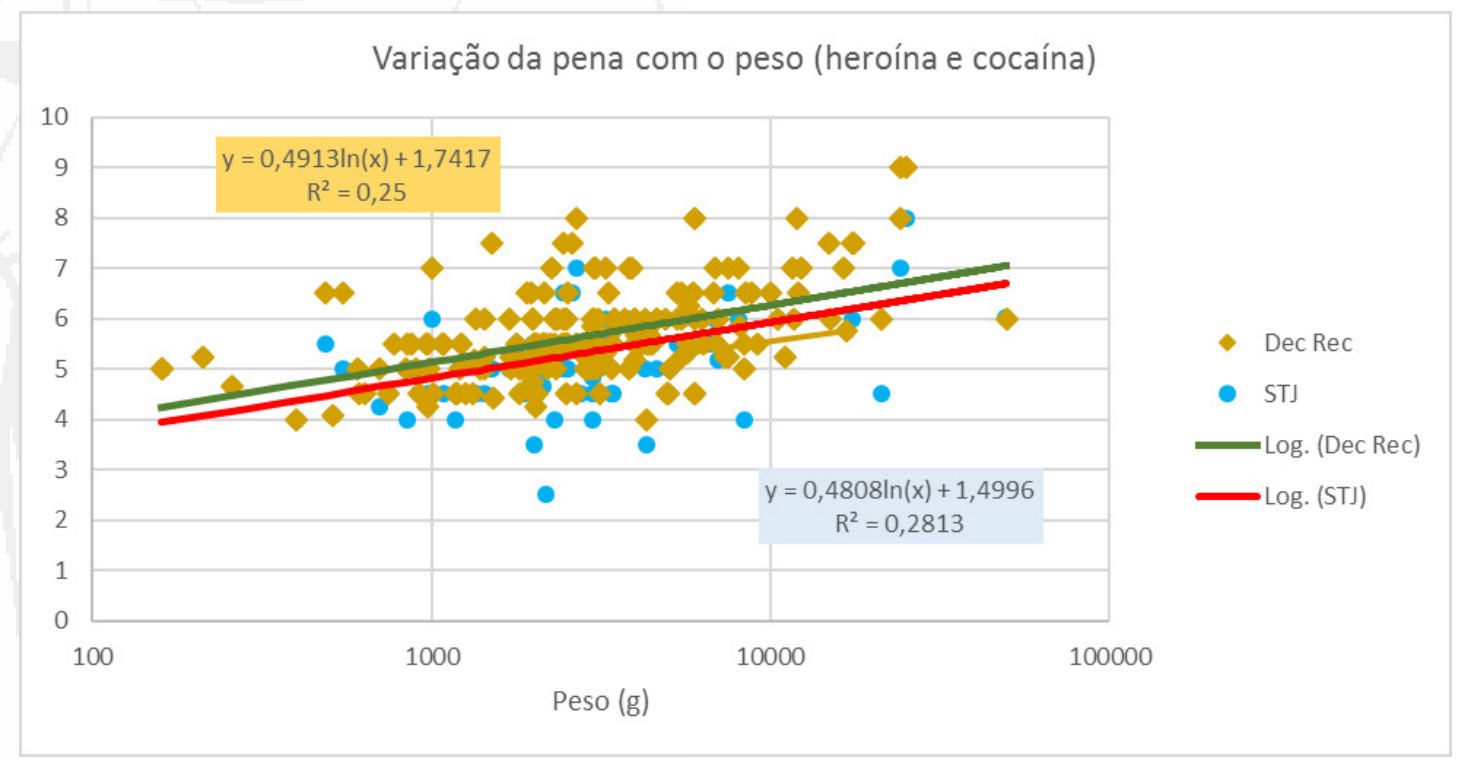

Figura 11 - Variação da pena nas decisões recorridas e no STJ com o peso (heroína e cocaína)

No estudo realizado em 2004 no STJ59 também se tentou estabelecer uma relação entre a quantidade de droga e a pena, utilizando-se uma regressão logarítmica $P=A$. In $(Q)+B$ e marcando-se de forma distinta as penas da $1^{a}$ instância e do STJ:

59 M. Simas-Santos e Manuel Matos. A medida da pena no Supremo Tribunal de Justiça no Tráfico de Estupefacientes (esboço de um estudo empírico). RPCC, 2004, pág. 453 e segs. 


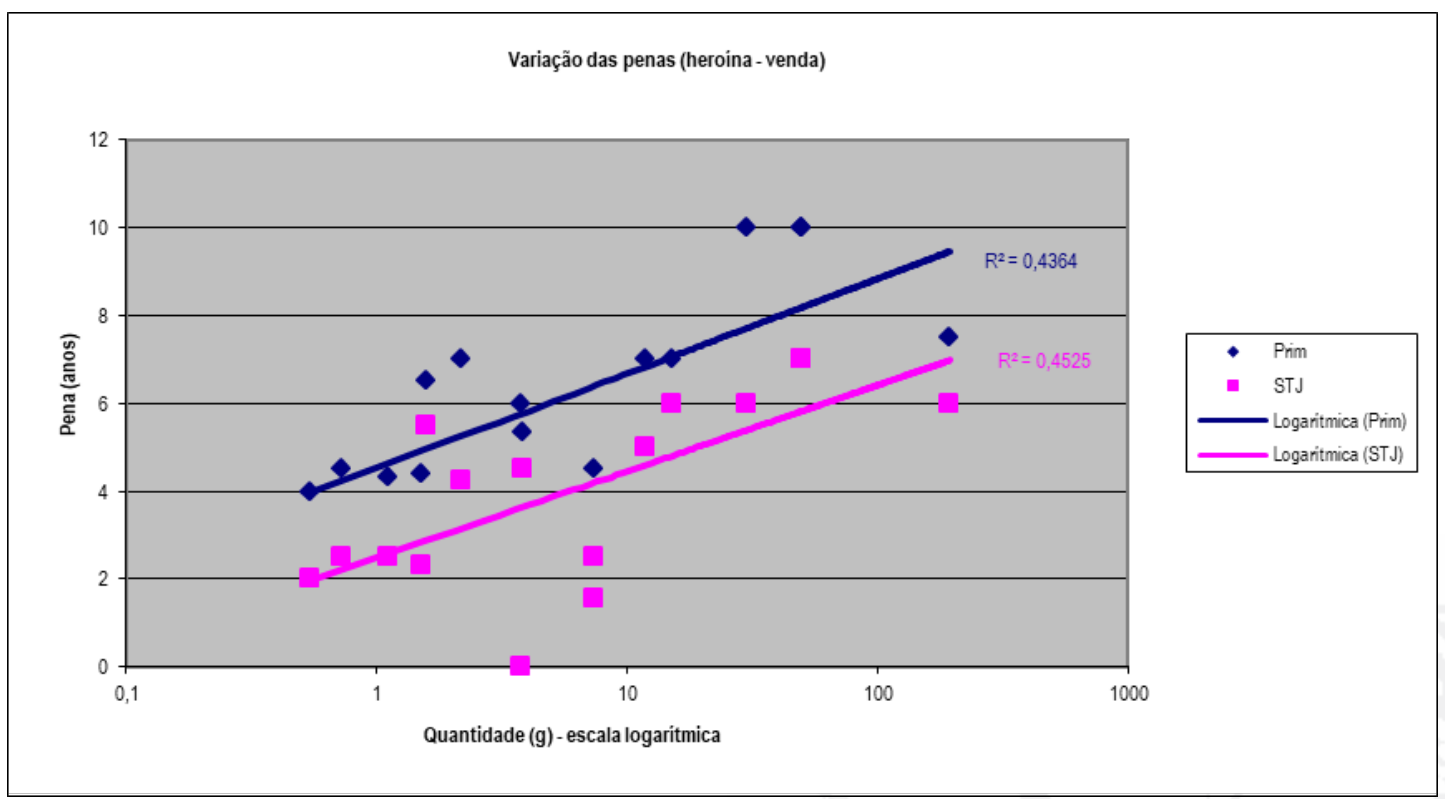

Figura 12 - Variação das penas -heroína e cocaína- (2004)

As rectas de regressão nos dois estudos têm inclinações semelhantes que permitem encontrar uma tendência típica: a relação entre a quantidade e a pena. No nosso estudo é de 0,49 para as decisões recorridas e de 0,48 para o STJ. Ordenada na origem mostra uma diferença ma origem de cerca de 3 meses $(1,74-1,5=0,24 \times 12)$, no estudo de 2004 era de 2 anos.

No estudo de 2004, a representação logarítmica mostra que nas quantidades baixas havia uma grande variação das penas com a quantidade. Nas quantidades mais altas a variação era pequena. Ex: a mudança de $1 \mathrm{~g}$ para 10 grs produz em média um aumento da pena de cerca de 2 anos, tanto como o aumento produzido em média por uma mudança de 10 grs para 100 grs. No nosso estudo, tratando-se de "correios de droga" com o perfil referido, as flutuações de quantidades são limitadas, diversamente do sucedido com o estudo de 2004, o que explica as diferenças encontradas.

Do estudo realizado e dos resultados obtidos, como já se adiantou, pode-se concluir-se que as secções criminais do STJ têm estado abertas à consideração das suas decisões anteriores em matéria de aplicação de penas no crime de tráfico de drogas por "correios de droga", com recurso mesmo a tabelas de recolha de dados relevantes para determinação das penas concretas, que acabam por funcionar como orientações facultativas nesse domínio, contribuindo para a 
Novos Estudos Jurídicos

promoção da coerência da aplicação das penas pelo próprio Tribunal, evitando a disparidade injustificada das penas, concentrando a maior parte das penas num "espaço" limitado da moldura penal abstracta prevista para o tipo de crime, sem embargo de aplicar penas situadas fora desse espaço quando a situação o justificar. Com efeito, $90 \%$ das penas aplicadas pelo STJ situam-se entre 3 anos e 9 meses e 6 anos e 9 meses; $80 \%$ entre 4 anos e 6 meses e 6 anos e mais de metade entre 4 anos e 9 meses e 5 anos e 9 meses.

Resulta ainda que o conhecimento, pelas instâncias, desta jurisprudência, reiteradamente mantida ao longo de 14 anos pelo STJ, tem feito o seu caminho e constituído orientação para essas mesmas instâncias que se tem vindo a aproximar da posição assumida pelo STJ.

Pensamos ser importante a tomada de consciência e divulgação desta realidade, a sua consideração na formação dos magistrados do Ministério Público e Judiciais, e a realização de estudos idênticos em relação a outros tipos de crimes que possam permitir a criação de guidelines indicativas para vários outros crimes delas carecidas.

BIBLIOGRAFIA

ANTUNES, Maria João, Consequências jurídicas do crime, Coimbra Editora, 2. a ed, 2015.

CANOTILHO, Gomes e MOREIRA, Vital, Constituição da República Portuguesa Anotada, I, Coimbra Editora, 2007

COUTINHO, Clara Pereira, Metodologia de Investigação em Ciências Sociais e Humanas: teoria e prática. $2^{\text {a }}$ ed. reimp. Coimbra: Almedina, 2016.

DIAS, Jorge de Figueiredo, Direito penal português. Coimbra: Coimbra Editora, Parte geral II: As consequências jurídicas do crime. - $2^{\mathrm{a}}$ reimpr. - 2009.

NEVES, Castanheira, "O princípio da legalidade criminal: o seu problema jurídico e o seu critério dogmático", in Estudos em homenagem ao Prof. Doutor Eduardo Correia I, AAVV (Coimbra: s/e, 1984), 307-469.

SIMAS-SANTOS, Manuel e LEAL-HENRIQUES, Manuel, Código Penal, 2. ${ }^{a}$ ed., Lisboa: Rei dos Livros, 1995, Vol. I, 
SIMAS-SANTOS, Manuel e LEAL-HENRIQUES, Manuel, Código Penal, 3. a ed., Lisboa: Rei dos Livros, 2002, Vol. I.

SIMAS-SANTOS, Manuel e LEAL-HENRIQUES, Manuel, O Código Penal de 1982, Lisboa: Rei dos Livros, 1986, Vol. I.

SIMAS-SANTOS, Manuel e MATOS, Manuel, A medida da pena no Supremo Tribunal de Justiça no Tráfico de Estupefacientes (esboço de um estudo empírico), RPCC, 4, 2004, pág. 453-507.

SIMAS-SANTOS, Manuel, e LEAL-HENRIQUES, Manuel, Noções de direito penal, 5. a ed. Lisboa: Rei dos Livros, 2016, actualizado por Manuel Simas Santos e João Simas Santos.

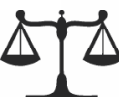

